\title{
FORMATION OF ENERGY RESOURCES POTENTIAL OF RURAL TERRITORIES
}

\author{
Roman Stupen, Oksana Stupen \\ Lviv National Agrarian University, Ukraine \\ romomas@ukr.net, oksanashufryn@ukr.net
}

\begin{abstract}
Taking into account the development of the market for energy crops and biofuels, the work substantiates the need to develop comprehensive public policy measures that will take into account the various functions of land resources (economic, environmental and social), as well as their role in the formation of energy resources in rural areas. The positive impact of the use of energy crops as raw materials for the production of biofuels on the conservation of ecosystems and the solution of issues concerning pollution and minimizing the trend of global warming was theoretically justified. The conducted researches allowed to identify and analyze the main groups of contradictions and conflicts of interest in the cultivation of energy crops for biofuel production: a negative impact on food security; increase in prices for food products; competition for energy cultures between the food and energy markets; competition for the use of natural resources (mainly land), competition in the energy market for fuels. The advantages of using biofuels from energy crops in agriculture are revealed. A theoretical and methodological approach to assessing the potential of growing energy crops for biofuel production is proposed, which, unlike existing ones, is based on the definition of the level of selfsufficiency of the territory by food using the coefficient of land-resource independence. Based on the results of the calculations, it is determined that the land and resource potential of the regions of Ukraine as a whole provides a high and satisfactory amount of food, except for two regions (Donetsk - 0.8 and Transcarpathian 0.5 ), and also allows the use of a significant amount of land resources for the cultivation of energy crops. The approach to development of the market of energy crops, which involves diversification of agricultural activity and land use depending on ecological and economic features of production, is grounded.
\end{abstract}

Keywords: potential, assessment, energy crops, biofuels.

\section{Introduction}

Sources and types of energy are continuously changing and improving in this sector of the economy in the process of development of agrarian technologies. Different sources of energy consumption are used in agricultural production: from photosynthesis and energy assimilation by soil organisms to man-made energy (fuel, electricity, gas and coal). Therefore, the issue of production and use of biofuels plays an important role in the accelerated development of innovative processes in agriculture.

The problem of energy independence of rural areas has been actively discussed in Ukraine only in the last few years in connection with the acute crises in the energy sector. Planning and solving of current tasks of increasing energy efficiency are possible only on the basis of the use of own energy resource potential of agricultural production. Energy resource potential can be characterized as a multi-faceted system of energy resources, which are in the interconnection and interdependence in the conditions of development of innovation processes. Therefore, the issue of production and use of biological fuel (biofuels) plays an important role in the accelerated development of innovative processes in agriculture. All this characterizes the special relevance and practical significance of the research problem - increasing the economic efficiency of the functioning of agricultural producers on the basis of biofuel use in the development of innovative agricultural processes. In view of this, the task of meeting the growing needs of rural areas in energy resources, along with the provision of environmental safety, necessitates the development of bioenergy potential of the agrarian sector. Bioenergy resources are considered as an important resource for diversifying energy sources and ensuring energy security, rural development, and for mitigating the effects of climate change by reducing greenhouse gas emissions.

\section{Materials and methods}

The information base of the study was compiled by the materials and reports of the State Statistics Service of Ukraine, as well as the analytical review of the market for energy crops according to the data of the Ministry of Agrarian Policy and Food. To study the interconnections between the agrarian sector and the energy market, the method of system analysis was used. The theoretical and methodical approach to assessing the potential of growing energy crops for the production of biofuels is proposed, which, unlike existing ones, is based on the definition of the level of self-sufficiency of the territory by 
food using the coefficient of land-resource independence. In the process of evaluating the potential of growing energy crops for biofuel production, we used O. Kravchuk methodology on the definition of the level of self-sufficiency of the territory by food, taking into account the specifics of the bioenergy market.

\section{Results and discussion}

It was revealed that the increase of economic efficiency of agricultural production is possible on the basis of the formation of own energy resource potential of rural territories. Resource balancing makes it possible to determine not only the structure of resources that are part of the energy resource potential, but also the effect of using biofuels and energy crops.

At the same time, the level of energy, ecological and economic efficiency of different variants of energy crop use is directly related to state policy in the field of biofuels [1]. On this basis, the energy resource potential of agriculture is understood as part of the production potential, which is a set of raw material resources of agricultural production and allows taking into account the ecological and economic advantages of using energy crops for the production of biofuels.

The overall ecological and economic effect of biofuel production will be determined by an increase in the level of energy security of the country, in particular due to a more stable supply of energy resources to the agrarian sector, produced from its own renewable sources, which will facilitate [2-4]: reducing the dependence of the national economy on traditional energy resources; diversification of production; improvement of the ecological situation; increase of export potential of the country; ensuring sustainable development of rural areas; raising the level of employment of the population.

The development of biofuels entails a number of serious changes in the food, agriculture and energy sectors (Figure 1). This leads to increased competition in existing markets and the emergence of new market opportunities. Depending on the initial situation, either the first or second tendency will prevail, turning the issue of energy crop market for biofuel production and food security into a set of contradictions [5-7].

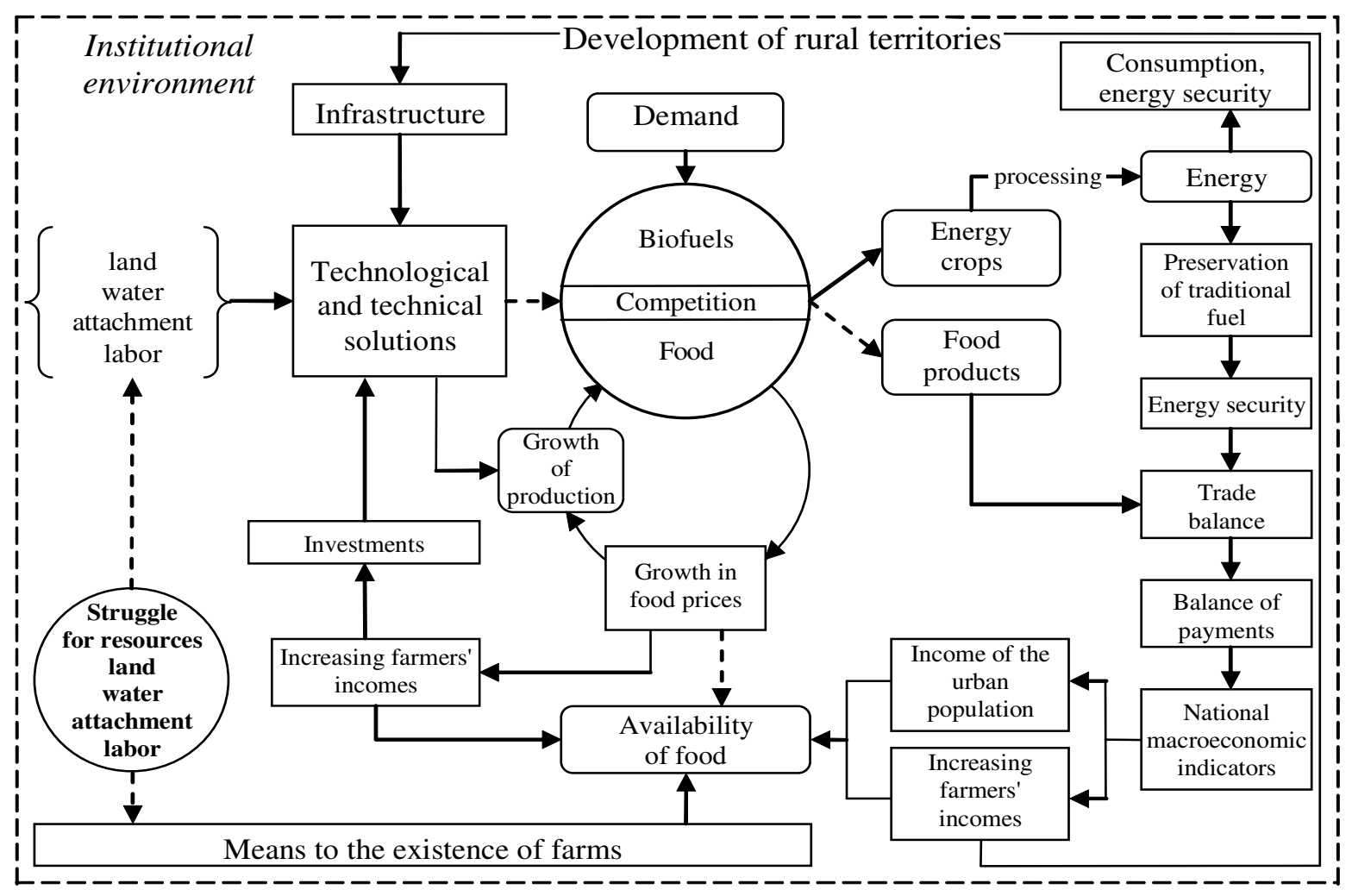

Fig. 1. Main consequences and corresponding reaction in system of agriculture and energy associated with emergence of demand for energy crops 
The conducted studies allowed to identify and analyze the main groups of contradictions and conflicts of interest in the cultivation of energy crops for the production of biofuels: the negative impact on food security; increase in prices for foodstuffs; competition for energy crops between the food and energy markets; competition for the use of natural resources (mainly land) competition in the energy market for fuels.

Organizing the production of raw materials for biofuels is one of the most important factors in increasing their efficiency. At the same time, function of the organization has own set of factors, which are also important for increasing the efficiency of biofuel production. So, for the development of bioenergy in agriculture, it is necessary to create conditions for the cultivation and sale of energy crops as biosources for their production.

With the development of the market for energy crops and biofuels, there is the need to develop comprehensive state policy measures that take into account the diverse functions of land resources (economic, environmental and social), as well as their contribution to food, energy and environmental safety. This is due to the format of competition for food and energy crops, natural resources, and, depending on the type of selected biosources, the needs for land resources change, which in turn changes the system of land use.

Consequently, the modern process of forming a market for energy crops for the production of biofuels is complex and to some extent contradictory. In view of this, the most urgent issue is the definition of efficient and competitive types of raw materials for the production of biofuels, taking into account the provision of a positive contribution to the preservation of the natural environment while minimizing the negative energy, environmental and social consequences.

In assessing the potential impact of increasing the production of biofuels for emissions, it is necessary to consider the extent, to which production growth will be achieved through increased productivity of agricultural lands, and in which, due to the expansion of cultivated areas. Both of these factors largely determine other types of environmental impacts of growing energy crops associated with land and water resources. Thus, the use of any energy crop for biofuels creates competition for land resources, which can not but affect food security. However, in our opinion, this aspect should be determined for the ecological and economic conditions of a particular territory.

Indeed, most assessments of the potential of biofuels and biomass resources focus on the allocation and use of land for the cultivation of food crops or cellulosic energy crops; this division is associated with potential consequences for land use [5].

In order to determine the real possibilities of the territory for providing food to the population, it is proposed to adopt a basket of grain crops as a starting point for assessing food independence (to ensure a balanced diet of one person, about $12.41 \mathrm{cwt}$ of grain per year are needed), since they are the main food product and raw material for biofuel production in Ukraine [8; 9].

In order to solve the problem of competition for land resources within a certain territory it is necessary to assess the real potential of the agricultural sector in providing food for its population. Obviously, the food potential of the territory depends on the area of agricultural land and the effectiveness of its use. To determine the level of self-sufficiency of the territory by food and the identification of potential opportunities for the production of energy crops, we propose the introduction of an indicator such as the coefficient of land-resource independence (1).

$$
C_{i}=\frac{A_{a}}{\left(A_{c} / Y_{c}\right)},
$$

where $C_{i}$ - coefficient of land-resource independence;

$A_{a}$ - area of agricultural land for 1 person, ha;

$A_{c}$ - annual amount of cereals necessary to provide food for 1 person, cwt;

$Y_{c}$ - yield of grain crops, cwt per ha.

Such a technique makes it possible to assess the real possibilities for self-sufficiency of food of one or another territory, depending on the availability of land resources of the agrosphere. In accordance with this methodology, three levels of self-sufficiency of food can be identified [6] (Table 1). 
Table 1

Evaluating the level of self-sufficiency of the area by food and the potential of growing energy crops for biofuel production

\begin{tabular}{|c|c|c|}
\hline $\begin{array}{c}\text { Level of self- } \\
\text { sufficiency in food }\end{array}$ & $\begin{array}{c}\text { Magnitude of the } \\
\text { coefficient of land- } \\
\text { resource independence }\end{array}$ & $\begin{array}{c}\text { Potential opportunities for growing energy } \\
\text { crops for biofuel production }\end{array}$ \\
\hline Very high & $C_{i}>3$ & $\begin{array}{c}\text { Very great potential for the use of surplus land } \\
\text { resources for the provision of energy resources } \\
\text { at the expense of agricultural crops and its } \\
\text { neighboring regions }\end{array}$ \\
\hline High & $3>C_{i}>1$ & $\begin{array}{c}\text { Sufficient potential for the use of surplus land } \\
\text { resources for the cultivation of energy crops }\end{array}$ \\
\hline Satisfactory & $C_{i}=1$ & $\begin{array}{c}\text { The land resource potential of the existing } \\
\text { efficiency of its use makes it possible only } \\
\text { self-provision of food }\end{array}$ \\
\hline Low & $C_{i}<1$ & $\begin{array}{c}\text { The available land resources for the existing } \\
\text { efficiency of their use are not enough for self- } \\
\text { provision of food }\end{array}$ \\
\hline
\end{tabular}

Using the technique made it possible to make a differentiation of regions of Ukraine according to the coefficient of land and resource independence (as of 2016) [10] and rank them in terms of food self-sufficiency and potential for growing energy crops for biofuels (Table 2).

Table 2

Grouping of regions of Ukraine by the level of self-sufficiency of food

\begin{tabular}{|c|c|c|}
\hline Level of food self-sufficiency & Region / Area & $\begin{array}{l}\text { Magnitude of the coefficient of } \\
\text { land-resource independence }\end{array}$ \\
\hline \multirow{10}{*}{ Very high } & Kirovohrad & 5.9 \\
\hline & Poltava & 5.5 \\
\hline & Chernihiv & 5.2 \\
\hline & Sumy & 4.7 \\
\hline & Cherkassy & 4.7 \\
\hline & Kherson & 4.2 \\
\hline & Khmelnytsky & 4.0 \\
\hline & Vinnytsia & 3.8 \\
\hline & Mykolaiv & 3.5 \\
\hline & Ternopil & 3.1 \\
\hline \multirow{10}{*}{ High } & Zhytomyr & 2.8 \\
\hline & Zaporizhia & 2.5 \\
\hline & Kharkiv & 2.2 \\
\hline & Volyn & 1.9 \\
\hline & Odessa & 1.9 \\
\hline & Rivne & 1.9 \\
\hline & Dnipropetrovsk & 1.7 \\
\hline & Chernivtsi & 1.3 \\
\hline & Kyiv & 1.1 \\
\hline & Lugansk & 1.1 \\
\hline \multirow{3}{*}{ Satisfactory } & Crimea & 1.0 \\
\hline & Ivano-Frankivsk & 1.0 \\
\hline & Lviv & 1.0 \\
\hline \multirow{2}{*}{ Low } & Donetsk & 0.8 \\
\hline & Transcarpathian & 0.5 \\
\hline
\end{tabular}


From the data provided, it is clear that the land-resource potential of the regions of Ukraine generally provides high and satisfactory food supplies (excluding the four regions), and also allows the use of a significant amount of land resources for the cultivation of energy crops. Consequently, the indicator proposed by us gives an opportunity to evaluate not only the possibilities of self-sufficiency of food of certain territories, but also their energy resource potential.

It should be noted that the calculations presented by us have a generalized character. Grain crops do not always prevail in the diet of the population of different countries [11]. In addition, soil resources in different countries and regions are heterogeneous and not always suitable for growing cereals.

\section{Conclusions}

1. The important direction of raising the economic efficiency of agrarian production is substantiated, namely, the formation of own energy resource potential of rural territories. The conducted ecological and economic analysis of the current state of the market of energy crops revealed a number of problems and prospects for the development of this sector of the economy. First of all, the ecological and economic impact is manifested in changing the conditions of land use. Thus, the use of any energy crop for biofuels creates competition for land resources, which cannot affect food security.

2. In order to assess the potential of growing energy crops for the production of biofuels, an approach that is based on determining the level of self-sufficiency of the food by using the coefficient of land-resource independence should be applied. Such a technique will allow to assess real possibilities for self-provision of food of one or another territory depending on the availability of land resources of the agrosphere, as well as to identify high potential opportunities for cultivating energy crops for the production of biofuels.

3. Based on the results of the calculations, it is determined that the land and resource potential of the regions of Ukraine as a whole provides a high and satisfactory amount of food, except for two regions (Donetsk -0.8 and Transcarpathian - 0.5), and also allows the use of a significant amount of land resources for the cultivation of energy crops.

\section{References}

[1] Fedorchenko B.S. Status and prospects of development of bioenergy potential of agricultural enterprises of Ukraine. Bulletin of the National Technical University "KPI". Technical progress and production efficiency. 2013, № 46, pp. 97-105.

[2] Kumar A., Purohit P., Rana S., Kandpal T.C. An approach to the estimation of the value of agricultural residues used as biofuels, Biomass Bioenergy. 2002, vol. 22, pp. 195-203.

[3] Kravchuk O.O. Ecological and economic peculiarities of the energy crops market formation. Economy of agroindustrial complex. 2013, № 5, pp. 135-141.

[4] Runge C., Senauer B. How biofuels could starve the poor. Foreign Affairs, 2007, vol. 86 (3), pp. 41-53.

[5] Turdiyeva Z.M. Indicators for assessing the resource potential for use of biofuel in agriculture. International scientific journal. 2012, № 1, pp. 52-57.

[6] Carriquiry M.A., Timilsina G.R. Second generation biofuels: economics and policies. Energy Policy, 2011, vol. 95, 39(7), pp. 4222-4234.

[7] Omer A.M. Green energies and the environment, Renew. Sustain. Energy Rev. 2008, vol. 12, pp. 1789-1821.

[8] Sydoruk B.O. Features of the study of the bioenergy industry impact on the competitiveness of rural areas and individual agrarian formations. Sustainable development of the economy. 2015, № 4, pp. 116-123.

[9] Kravchuk O.O. Assessment of the impact of the production of energy crops for biofuels on food security in Ukraine. Economics and Entrepreneurship. 2013. № 11. pp. 153-158.

[10] Agriculture of Ukraine in 2016 Statistical Book. State Statistics Service of Ukraine. Kyiv, 2017 $360 \mathrm{p}$.

[11] Sethi V.P., Sharma S.K. Survey of cooling technologies for worldwide agricultural greenhouse applications, 2007, Sol. Energy 81, pp. 1447-1549. 